\title{
THE COMPARATIVE ANALYSIS OF HARMONIC HEARING DEVELOPMENT CONCEPTIONS BY DIFFERENT AUTHORS
}

\author{
Gaļina Zavadska
}

Daugavpils Universitāte

\begin{abstract}
Musical-pedagogical theory and practice of higher education have to address complicated issues: the content of musical education changes, new music teacher training forms develop, technical provision of a teaching process improves.Choral singing as a kind of collective music making is an integral component of Latvian culture, an irreplaceable and over centuries tried out factor of spiritual and creative development of a Latvian people. Harmonic hearing is one of the components of musical hearing. The aim of the paper: to present the analysis of works by different authors on issues of the development of harmonic hearing made on the basis of the criteria developed for the analysis of literature. The general pedagogical criteria for the evaluation of teaching aids and the didactic principles of content development from the methodological recommendations "The Development and Evaluation of the Content of Teaching Aids Complying with National Education Standards" (The Department of Pedagogy at the Faculty of Pedagogy and Psychology of the University of Latvia) were taken as a basis for the offered criteria of the analysis of methodological literature.
\end{abstract}

Research method: the comparative analysis of some theoretical conceptions within the context of the given research.

Key words: Harmonic hearing, the comparative analysis, criteria.

\section{Introduction}

The development of personality's creative abilities is of the key importance for the contemporary musical education. Creative activity is one of the main strategic principles whose application may essentially increase opportunities of Latvia's sustainable development (Strategy for Latvia's sustainable development until 2030, 2011). Musical activity is very specific by its nature and requires various musical abilities, emotional feeling and perception to be revealed. Relying on D. Campbell's research findings, J. Birzkops emphasizes the importance of music making for the development of different latent human abilities in the process of musical activity (Birzkops, 2000).

Choral singing, being a kind of collective music making, is an integral component of Latvian culture, an irreplaceable and over centuries tried out factor of spiritual and creative development of the Latvian people. Latvian musical culture is tightly linked with the tradition of singing together. Choral singing in Latvia was known already at the beginning of the 19th century. Even now singing in a choir for Latvians is "an important uniting element and testimony to their national identity" (Miezìte, Znutinšs, 2009:215).

The effectiveness of a musical activity depends first of all on the development of musical hearing. Harmonic hearing is one of the components of musical hearing. A consecutive an purposeful development of harmonic hearing is a necessary 
condition for many-voiced choral singing. The quality of intoning in a choir and a choral ensemble depend on the developmental level of harmonic hearing. A well-developed harmonic hearing is by right considered a high stage of professional musical hearing and is of great importance for a prospective music teacher. It expands possibilities of sight-reading choral scores, speeds up the process of learning them, deepens the perception of polyphonic music, improves students' self-control over performing the compositions, which all is very important under the conditions of choral traditions of Latvian musical culture.

The aim of this paper is: to give a comparative analysis of conceptions provided in works by different authors concerning the issue of the development of harmonic hearing.

Research methods: the comparative analysis of harmonic hearing development conceptions by different authors made by applying the proposed criteria.

\section{Research Methods and the Procedure}

To evaluate the significance of theoretical conceptions by different authors (Kārkliņš, 1963; Joffe, 1991; Maslenkova, 2003) the criteria for the analysis have been determined. The basis of the proposed criteria of the analysis is the recommendations "Valsts vispārējās izglīî̄bas standartiem atbilstošas mācību literaturas izstrāde un izvērtěšana" [The development and evaluation of educational literature which complies with the national general education standards]. The general pedagogical didactic principles were formulated by scholars of the Department of Pedagogy and Psychology at the University of Latvia (Valsts vispārējās izglīî̄bas standartiem atbilstošas mācību literatūras satura izstrāde un izvērtěšana, 2010). The criteria of pedagogical evaluation worked out by M. Sīle were also partially used (Sīle, 2003). The developed principles are, first of all, oriented to educational literature for general education schools. Therefore, from the whole list of criteria those which might be important for the analysis of the development of harmonic hearing conceptions were selected. Therefore the following criteria have been selected for the analysis:

Systematism;

Regularity;

The principle of the didactic material organization;

The principle of the selection of practical musical material.

The principle of systematism is applied to structure the educational content in accordance with the logic of the subject and practice, so as to make the acquisition of the subject easier. Its essence lies in the branch of the subject (science), in the field of practice - in internal connections between respective theoretical and practical findings. 
The principle of systematism also determines the regularity and periodicity of the organization of studies, so that the students' achievements should be qualitative. It is manifested in the structuring of the content, in mutual consecutiveness and unity of educational tasks, in the choice of teaching/learning methods (Valsts vispārējās izglīitības standatriem atbilstošas mācību literatūras satura izstrāde un izvērtēšana, 2010). The principle of the didactic material organization determines that the offered educational content is organized in compliance with the logic of science or practice and can fall into linear, spiral and parallel principles.

The spiral principle means that - before mastering a new stage of difficulties, the authors return to the revision of the material of previous stage of difficulties (Sīle, 2003: 97). While the parallel principle implies that the linear principle of gradual complicating the material and parallel introduction of a new material should occur simultaneously. The principle of the selection of practical music material is based on the author's selection of music examples, depending on specific style, genre, folklore and other priorities.

Works by three authors were selected for the comparative analysis:

Kārkliņ̌š, L. (1963). Mūzikas teorētisko priekšmetu mācīšanas metodika.

[Methodology of Teaching Theoretical Subjects in Music];

Joffe, J. (1991). Muzikālās dzirdes attīstìbas ceļi. [Ways of the Development of Musical Hearing];

Масленкова, Л. (2003). Интенсивный курс сольфеджио [Maslenkova, L.

Intensive Course in Sol-Fa. Methological Aid for Teacher].

The selection of these particular works for a comparative analysis was determined by the fact that the conceptions of the development of harmonic hearing offered by the Latvian authors L. Kārkliņš and J. Joffe have laid a foundation for Latvian musical education, and the methodology of teaching solfa in Latvia is based on the conceptions of these authors. The choice of the work by the Russian author L. Maslenkova was dictated, on the one hand, by longterm links between the musical science of Latvia and Russia (both authors - L. Kārklinšs and J. Joffe - received their education in Russia) and common tendencies in the development of musical education, and on the other hand, by the fact that L. Maslenkova has taken a new approach to dealing with the problem of training musical ear of musicians-professionals, by forming and developing their musical thinking on the basis of the contemporary 20th century music and broad historical-theoretical knowledge, thus developing awareness of the process of perception.

Methodology of Teaching Theoretical Subjects of Music by L. Kārklin̄̌s (1963) is addressed to teachers of musical-theoretical disciplines in music secondary schools. In this work there is a whole chapter devoted to the problem of developing harmonic hearing: The Development of Harmonic Hearing (pp. 9095). 
Methodological recommendations are based on the principle of gradual complicating the material. The author proposes to begin the development of harmonic hearing by mastering intervals:

singing intervals harmonically;

adding accompaniment to singing;

analysis by ear - determining intervals by ear.

L. Kārkliņš proposes a timbral system for determining intervals by ear:

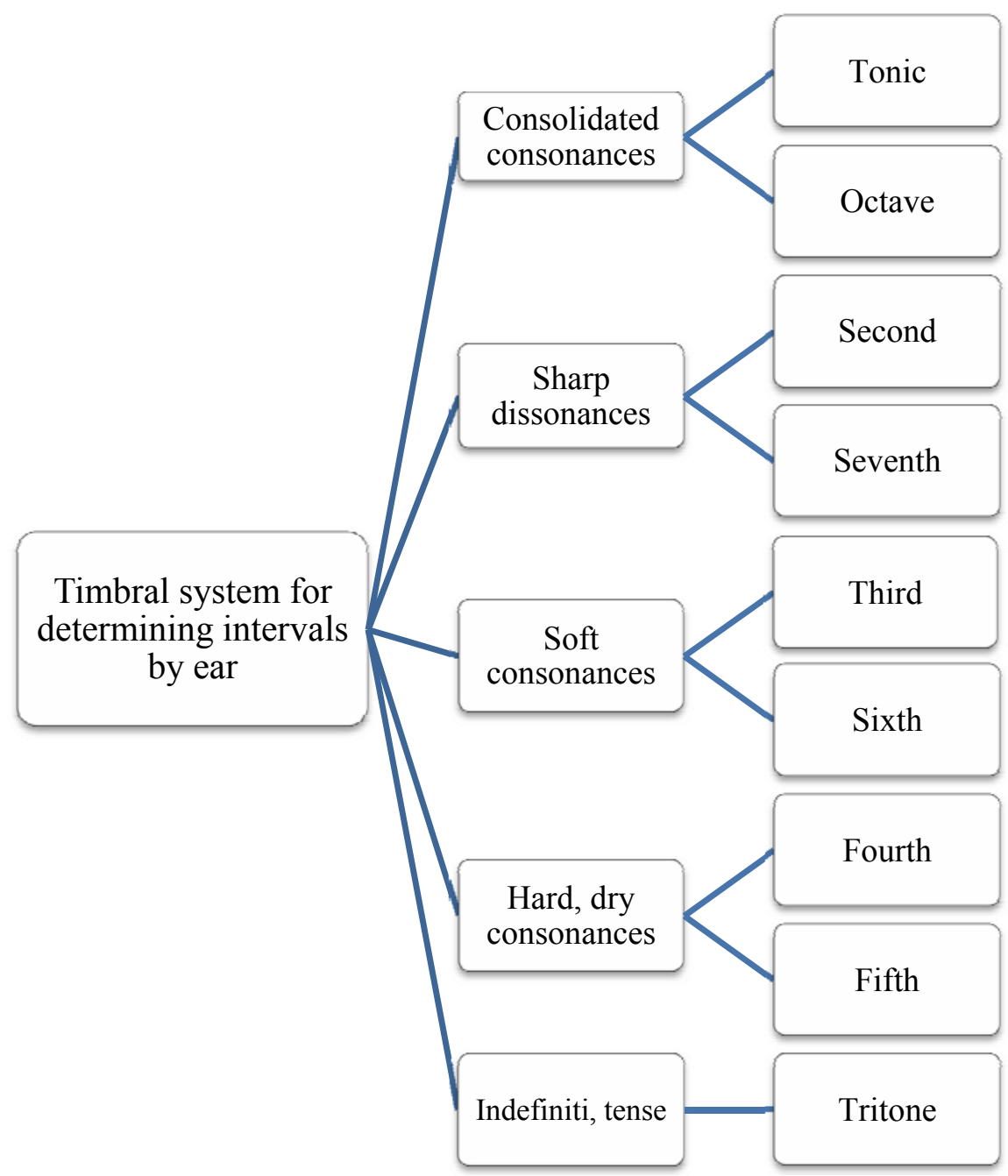

Figure 1. Timbral system for determining intervals by ear (according to L. Kärklinšs)

According to this system, L. Kārklinšs recommends the following: "each group of intervals is given a brief characterization concerning its timbre; and this is what the interval is determined by" (Kārkliņš, 1963: 91).

When the intervals have been mastered, the next stage is to master three-part singing according to the following scheme worked out by the author: 


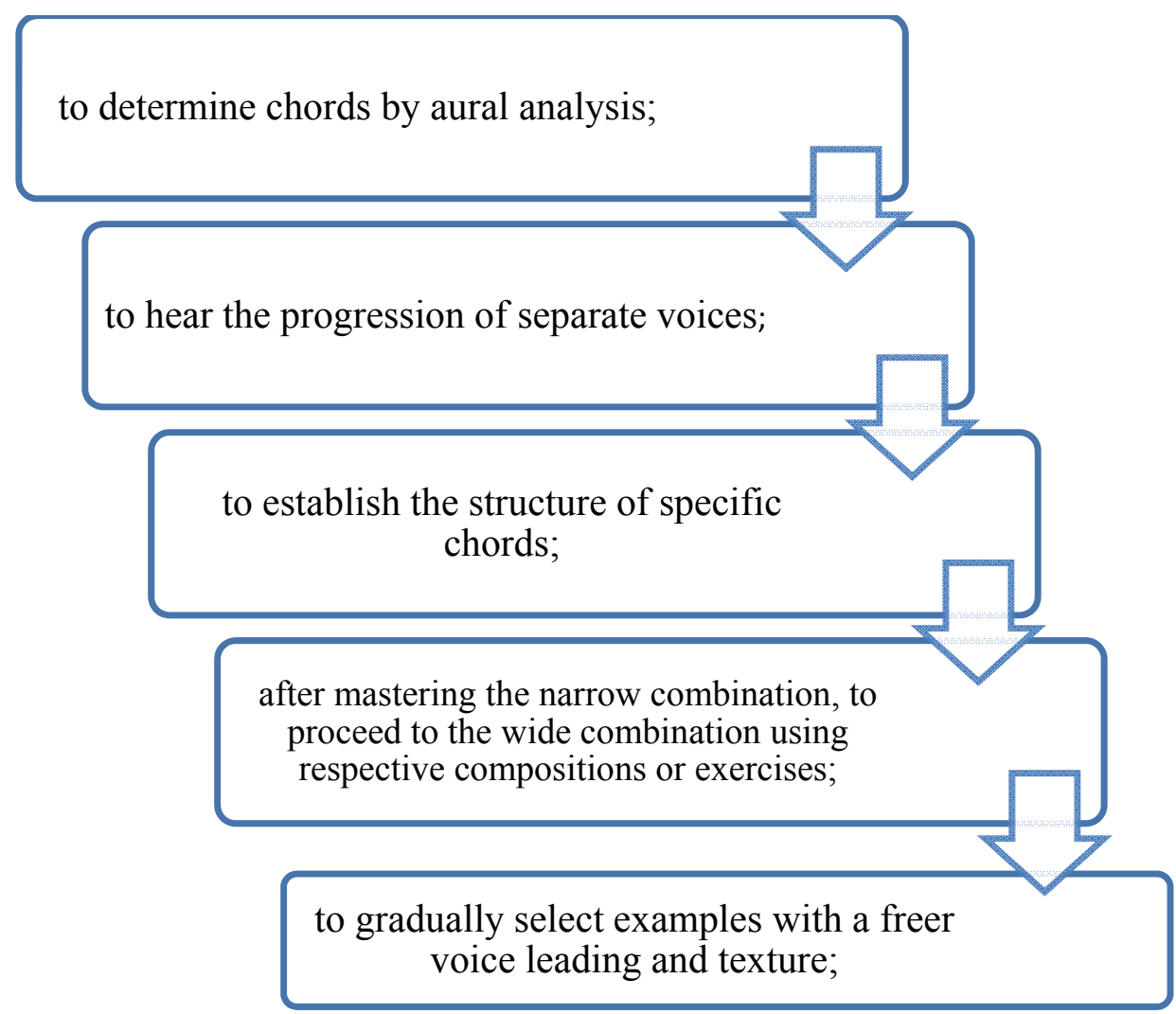

Figure 2. Sequence of mastering three-part singing (according to L. Kārkliņš)

L. Kārkliņš proposes also different methods of aural analysis- homophone textures together with singing and writing down the parts. The author stresses the importance of independent work in small groups (groups of 2 or 3). An interesting technique is the technique offered by the author for reinforcing the ability to hear the function of a chord - to sing bass and to play the score of choir songs.

L. Kārklinš attracts attention to the essential role that theoretical knowledge and singing play for the development of harmonic hearing. The author touches upon this issue also in chapter which deals with inner hearing - composing the accompaniment to a familiar melody, writing the melody of harmonic accompaniment in notation without the help of an instrument (Kārklinšs, 1963, 99-100).

The linear organization of educational content is implemented in the methodological teaching aid by L. Kārkliņšs.

Ways of the Development of Musical Hearing by J. Joffe (1991) is addressed to teachers of music schools, to students and lecturers of music secondary schools and higher education establishments. The author applies the linear principle the scale of gradual overcoming difficulties. By this he understands a system which is substantiated in science and verified in practice.

J. Joffe draws attention to the vague and inaccurate requirements of the curriculum with regard to the development of harmonic hearing in music 
schools and music secondary schools. The author builds his own conception of the development of harmonic hearing on the analysis of two-part examples from the collections of the Russian authors - "Sol-Fa" by I. Sposobin and B. Kalmikov, and two-part sol-fa by G. Fridkin. J. Joffe arranges intervals into three groups (letters $\mathrm{S}$ and $\mathrm{V}$ for strong and weak time-parts):

Scale of intervals for the development of harmonic hearing (according to J. Joffe)

\begin{tabular}{|c|c|c|}
\hline $\begin{array}{l}\text { The first group of } \\
\text { intervals }\end{array}$ & The second group & The third group \\
\hline seconds $-\mathrm{I}_{\mathrm{SV}}, \mathrm{IV} \mathrm{SV}_{\mathrm{S}}$ & $\begin{array}{c}\text { seconds }-\mathrm{V}_{\mathrm{v}}, \mathrm{VI} \mathrm{SV}_{\mathrm{SV}} \\
\mathrm{VII}_{\mathrm{S}}, \mathrm{II}_{\mathrm{SV}}, \mathrm{III}_{\mathrm{SV}}\end{array}$ & seconds $-\mathrm{V}_{\mathrm{S}}, \mathrm{VII}_{\mathrm{V}}$ \\
\hline thirds $-\mathrm{I}_{\mathrm{SV}}, \mathrm{III}_{\mathrm{SV}}, \mathrm{V}_{\mathrm{S}}$ & $\begin{array}{c}\text { thirds }-V_{v}, I_{\mathrm{sV}} \\
\text { IV }_{\mathrm{sV}}, \mathrm{VII}_{\mathrm{sV}}\end{array}$ & third $-\mathrm{VI}_{\mathrm{SV}}$ \\
\hline fourths $-V_{s v}, I V_{V}, I_{V}$ & $\begin{array}{c}\text { fourths }-\mathrm{IV}_{\mathrm{s}}, \mathrm{I}_{\mathrm{s}}, \mathrm{II}_{\mathrm{sV}}, \\
\mathrm{VII}_{\mathrm{V}}, \mathrm{VI}_{\mathrm{V}}\end{array}$ & $\begin{array}{l}\text { fourths }- \text { III }_{\mathrm{sV}} \\
\text { VII }_{\mathrm{V}}, \mathrm{VI}_{\mathrm{S}}\end{array}$ \\
\hline fifths $-V_{s v}, I_{s V}$ & $\begin{array}{l}\text { fifths }- \text { VII } \mathrm{sv}, \mathrm{VI}_{\mathrm{V}} \text {, } \\
\text { II }_{\mathrm{SV}}, \mathrm{III}_{\mathrm{SV}}, \mathrm{IV}_{\mathrm{V}}\end{array}$ & fifths - IV ${ }_{s}, V_{s}$ \\
\hline sixths $-\mathrm{III}_{\mathrm{SV}}, \mathrm{VII}_{\mathrm{SV}}$ & $\begin{array}{c}\text { sixths }- \text { IV }{ }_{\mathrm{sv}}, \mathrm{V}_{\mathrm{sV}} \\
\mathrm{VI}_{\mathrm{SV}}, \mathrm{II}_{\mathrm{sV}}\end{array}$ & sixth $-I_{S V}$ \\
\hline seventh- $\mathrm{V}_{\mathrm{SV}}$ & $\begin{array}{c}\text { sevenths }- \text { II }_{\mathrm{sv}}, \mathrm{I}_{\mathrm{sV}} \\
\text { III }_{\mathrm{SV}}, \mathrm{IV}_{\mathrm{SV}}\end{array}$ & $\begin{array}{c}\text { sevenths }-\mathrm{VI}_{\mathrm{SV}}, \\
\mathrm{VII}_{\mathrm{SV}}\end{array}$ \\
\hline
\end{tabular}

The first group of intervals has to be mastered during the initial stage of training, and then the less frequent intervals in the second group and the third group.

J. Joffe recommended employing this interval scale at deciding on the level of difficulty of dictations. According to the author, the practical side of the methodology includes such tasks as:

- to sing intervals in a definite mode;

- to reinforce them with the help of sequences;

- to determine intervals by ear;

- to do different creative exercises.

An important factor of mastering harmonic interval system, as proposed by $\mathrm{J}$. Joffe, is the assertion that the perception of the interval group depends on the time and metro-rhythm conditions in which this interval appears - metric position, rhythm pattern of the interval, and time and timbre as well.

The next stage is - interval as a part of a chord. As recommended by J.Joffe, one kind of creative task for mastering harmonic intervals may be variation dictations. For instance, after writing a two-part dictation, composing of variations on the just introduced theme follows. 
J.Joffe also suggests that schemes of different variants could be used for mastering chords, because they help students to acquire theoretical knowledge of the fundamentals of harmony, e.g.:

1. resolution of chords;

2. place of chords in a mode;

3. standard tables of chord sequences.

Teachers are advised to use team games, because they make students more active and responsive at sol-fa classes (Joffe, 1991).

Unfortunately, J. Joffe does not offer any practical material, however the methodological material is structured according to the spiral principle.

The teaching aid on intoning and aural perception (analysis) of contemporary music Modus novus (1963) designed by the Swedish author L. Edlund is of great interest. This book presents the summary of results of author's own pedagogical experience obtained in the Royal Higher Music School in Stockholm. Here L. Edlung offers his own methodology of teaching contemporary sol-fa, and it is aimed at developing the musical perception of intervals outside the major-minor context (Edlund, 1963). This teaching aid is built on the principle of gradual mastering of intervals within the 20th century atonal music context. Each chapter is introduced by methodological recommendations in three languages Swedish, German and English. Each chapter has four parts: an isolated interval (or a group of intervals), interval models of exercises, performance of the melody by syllables without mentioning the note names - a'capella, chord series. The logic of building the practical musical material is based on opposing stability to instability, tonal support to non-support, consonance to dissonance. In some chapters $(4,8$ and 11) fragments from the compositions of the 20th century composers (S. Bartok, A. Webern, I. Stravinsky, P. Hindemith, A. Schenberg etc.) are provided. No doubt, the teaching aid developed by L. Edlund offers one of the possible ways for mastering the intonation and aural wealth of the 20th century music.

The interval approach, applied as a basis for the development of harmonic hearing through the perception of elements of a sounding complex, is characteristic of a French school - Y. Desportes Comment former l'oreille musicale (1970). The process of intoning, determining and recording some consonance takes place by means of singling out intervals in consonances. According to the recommendations of Y. Desportes, when chords are analyzed it is necessary to name sounds which these chords contain. But it is not compulsory at all to determine the functions of chords. The sounds in a chord are determined on the basis of the tuning-fork sound "la" rather than on the basic (lowest) sound of the chord (outside the context) (Desportes, 1970). Thus, the functional quality of chords is to some extent leveled.

Some methodological recommendations on determining (analysis) the chords by ear are proposed by the leading contemporary Latvian music theoretician I. Grauzdina in her work Aural Analysis at Sol-Fa Classes in Children's Music 
Schools (1975). These recommendations are based on the perception of modefunctional connections in the harmony. Aural analysis could be done in the sequence as follows:

- to determine separate chords in a narrow composition according to the structure and color of their intervals,

- to determine the place and functionality of separate chords in the mode,

- to determine small chord sequences of a narrow composition in the mode,

- to hear the functional development of a larger structure (sentence, period) in a freer texture,

- to hear the characteristic harmonies of a fragment from some composition (Grauzdina, 1975).

Methodological recommendations given by I. Grauzdina are based on the perception of mode-functional connections in the harmony.

The book Intensive Course of Sol-Fa by L. Maslenkova (2003) is one of the contemporary methodological works concerned with the problems of the development of musical hearing and is addressed to teachers of sol-fa.

The author understands harmonic hearing as "the ability to perceive and distinguish consonances and the connections between them" (Maslenkova, 2003: 79). L. Maslenkova considers that the components of harmonic hearing are the sense of phonism, functionality, voice leading. This can be visualized in a scheme as follows:

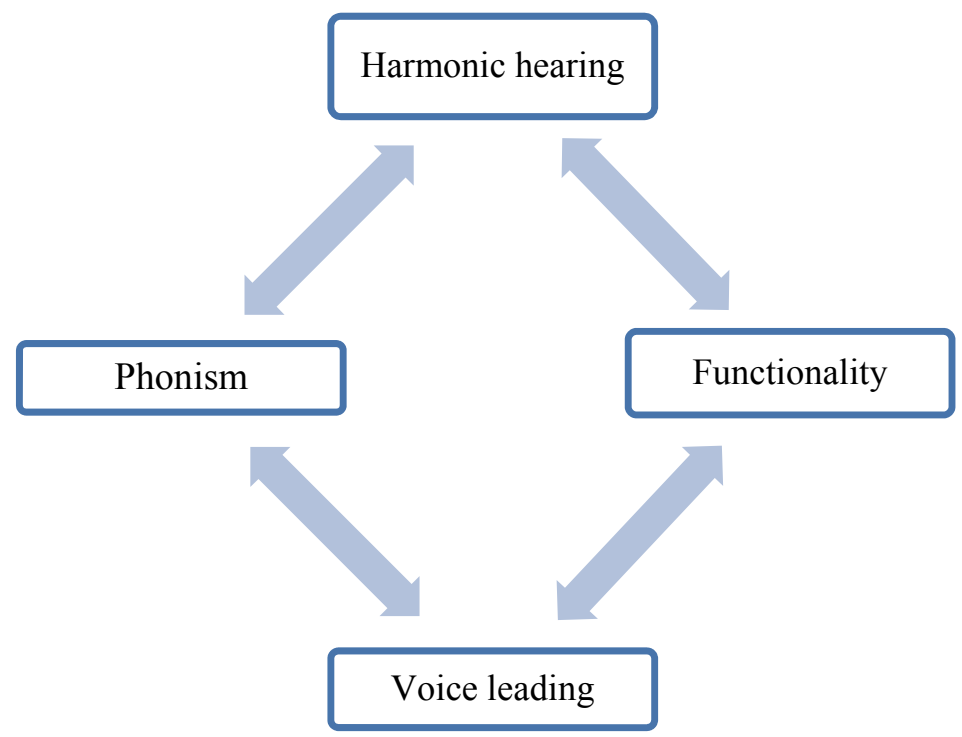

Figure 3 Components of harmonic hearing (according to L. Maslenkova)

The author of this paper offers the methodology of developing harmonic hearing worked out by her in these three directions. The author recommends starting the development of harmonic hearing with learning intervals, and defines four stages of this work: 
The 1st stage - intervals are distinguished by their timbral characteristics - consonance or dissonance.

The 2nd stage - spatial characteristics of the interval - the degree of the distance between notes within the frame of an octave.

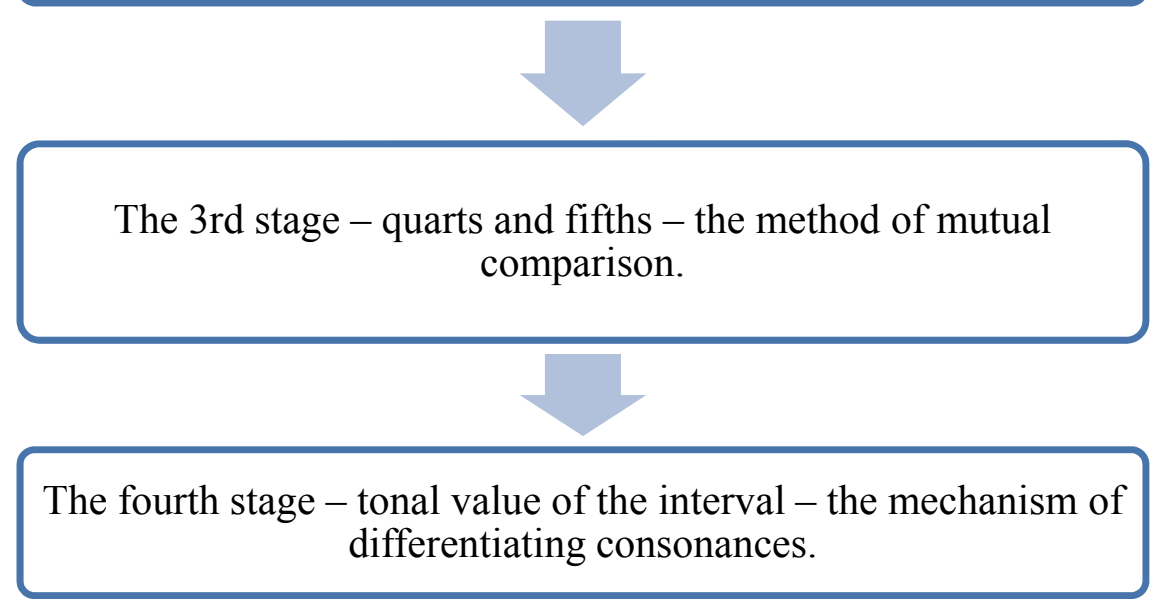

Figure 4 Stages of mastering intervals (according to L. Maslenkova)

The author asserts that to train memorizing isolated intervals is pointless. It is much more useful to memorize interval sequences in blocks and to use for this purpose different variants of combinations. The tempo of training intervals is of great importance, and it should be quick. A quick tempo facilitates "mobilization of attention and quick activity of brain" (2003: 83).

The next stage - work on three-part singing and the following process of increasing complexity takes place in four-part singing conditions. For this, a number of instructive examples illustrating this method are added. Learning of 3-part and 4-part harmonic consonances by their phonism is based on the impression obtained from a whole, undifferentiated consonance. And the principle of comparison/correlation of individual colouring of sounding is applied.

Functionality is a manifestation of the principle of subordination, stability and instability. The author suggests starting immediately with four-part singing in order to create the first impression about functionality. L. Maslenkova underlines the importance of demonstrating the differences in chord functionality on the examples of music of different composers rather than on harmonic schemes. Learning chords and mastering modulations take place simultaneously. 
In author's view, work on voice-leading involves differentiated hearing of texture "as a material embodiment of a live intonation process" (Maslenkova, 2003: 96). Voice-leading is understood as the ability of hearing to focus and hold attention on several voices, to follow their development, to be able to distinguish some voice from the whole and to follow the line of connections between chords in the whole.

The author asserts that work on voice-leading in 4-part singing is the basis of harmonic sol-fa, and sol-fa is the most important component of teaching musical hearing of choir conductors and, consequently, also that of music teachers. The book provides different exercises to activate aural attention.

The next chapter of L. Maslenkova's methodology is concerned with the problem of introducing into the educational process the romantic, impressionistic harmony and chord formations of the 20th century music. The consonances to be learnt include chords of the fourth and fifth, with the second next to some tone.

The author notes that harmonic hearing is a complex multi-component ability which is based on a physiological ability to distinguish harmonic consonances and to establish connections between them.

In L. Maslenkova's book is structured on the principles of linear and parallel organization of the material. The author offers her own solution to the problem of developing harmonic hearing, her own original methodology of educating a flexible, active musical hearing, based on different methods of comparison, correlations and analogies. However, though L. Maslenkova's work is certainly valuable, some principles seem to be disputable. It is hardly possible to agree with her statement that training to memorize isolated intervals is purposeless. The practice shows that only through perceiving and memorizing isolated intervals (which takes quite a long period of time) can we proceed to the blocks of intervals. The instruction concerning the quick tempo of work on training intervals seems to be disputable as well. Depending on the individual peculiarities of the group and the level of preparedness etc., the tempo of work may be different.

One of the latest conceptual works on issues of musical hearing is the book SolFa - Psycho-Technique of the Development of Musical Hearing by M. Karaseva (2009). The book provides the methodology of teaching sol-fa which is based on the Gestalt psychology and neuro-linguistic programming. Chapter 7 of this book deals with harmonic hearing (pp. 153-195). M. Karaseva touches upon problems of the analysis of a psychological aspect of musical hearing and distinguishes two ways of perceiving consonances:

- analytical (singing chords by sounds and then structuring them into the whole);

- $\quad$ synthetic (perception of the whole image of a chord). 
M. Karaseva provides her tables of VAK-sub-modalities (visual + auditory + kinetic characteristics and metaphors) of intervals and chords which can be modified. M. Karaseva gives also some practical recommendations and provides a complex of exercises oriented to training to hear four-part arrangement of chords. The author emphasizes that the succession of learning intervals and chords may be different (Karaseva, 2009).

Comparing the research under the analysis, we would like to discuss three authors - L. Kārklinšs, J.Joffe and L. Maslenkova - in more detail. Each of them proposes their own methodology of developing harmonic hearing, which can be partially applied at training prospective music teachers.

Speaking about the first criterion we can say that all authors apply the systemic principle, which completely reflects structuring of educational content in correspondence with the logic of the subject and practice. L. Kārkliņš offers a timbral system for determining intervals by ear and a scheme for acquiring three-part singing; J.Joffe has developed his own interval scale for the development of harmonic hearing and different variant schemes for learning intervals; L. Maslenkova defines the stages of mastering intervals and 3-4 part harmonic consonances by their phonism. All authors apply the principle: from the simple to the complex (from intervals to chords).

The principle of regularity, which underlies the regularity and periodicity of study organization to obtain students' qualitative performance, is also applied by all authors (L. Kārkliņš - partially).

The principle of the didactic material organization is applied by the authors differently. L. Kārklinšs and L. Maslenkova stick to the linear principle, though L. Maslenkova applies also the parallel principle at introducing the new material. Gradual mastering of the material and introduction of interesting techniques for making attention, memory and thinking active take place simultaneously. J. Joffe relies on the spiral principle of organizing the material.

L. Kārkliņš does not offer any practical material meant specially for pedagogical purposes, however the examples given are based on Latvian folklore, original Latvian choral music (E. Dārzinšs Sapņu tālumāa) and on the arrangements of Latvian folk songs for a choir (Lìgodama upe nesa arranged by O. Grāvitis). We can assume that if the author's aim had been to create a didactic teaching aid on harmonic sol-fa, the material would have been selected from the national-song repertoire. The tendency to increase the role of national-song themes of multinational character was a typical feature of the Soviet musical art in the 50ies of the 20th century. Naturally, this tendency was displayed in teaching aids on sol-fa and methodological materials too (Karaseva, 2009). Therefore we can say that, on the whole, the approach to teaching musical hearing which L. Kārklinšs has taken in his work is mode-based.

J. Joffe does not offer any practical material except small interval sequences. But the didactic material provided by L. Maslenkova is based on author's 
instructive exercises and the 20th c. contemporary music (fragments from compositions by B. Bartok, S. Prokofiev, D.Shostakovich).

The analysis of various conceptions done according to the proposed criteria can be schematically represented in the table.

Table 2

\section{Comparison of the conceptions by various authors according to the proposed criteria}

\begin{tabular}{|c|c|c|c|c|}
\hline Conceptions & $\begin{array}{c}\text { 1st criterion } \\
\text { Systematism }\end{array}$ & $\begin{array}{c}\text { 2nd } \\
\text { criterion } \\
\text { Regularity }\end{array}$ & $\begin{array}{c}\text { 3rd criterion } \\
\text { The principle of } \\
\text { didactic material } \\
\text { organization }\end{array}$ & $\begin{array}{c}\text { 4th criterion } \\
\text { The principle of } \\
\text { selection of practical } \\
\text { musical material }\end{array}$ \\
\hline $\begin{array}{c}\text { L. Kārklinšs } \\
\text { Methodology of } \\
\text { Teaching } \\
\text { Theoretical } \\
\text { Subjects of Music }\end{array}$ & + & partially & $\begin{array}{c}\text { Linear } \\
\text { organization of } \\
\text { the material }\end{array}$ & $\begin{array}{c}\text { Latvian folklore, } \\
\text { original Latvian choral } \\
\text { music }\end{array}$ \\
\hline $\begin{array}{c}\text { J. Joffe } \\
\text { Ways of the } \\
\text { Development of } \\
\text { Musical Hearing }\end{array}$ & + & + & $\begin{array}{c}\text { Spiral } \\
\text { organization of } \\
\text { the material }\end{array}$ & $\begin{array}{c}\text { No practical material } \\
\text { is offered }\end{array}$ \\
\hline $\begin{array}{c}\text { L. Maslenkova } \\
\text { Intensive Course of } \\
\text { Sol-Fa }\end{array}$ & + & + & $\begin{array}{c}\text { Linear and } \\
\text { parallel } \\
\text { organization of } \\
\text { the material }\end{array}$ & $\begin{array}{c}\text { Instructive author's } \\
\text { exercises of the 20th c. } \\
\text { contemporary music }\end{array}$ \\
\hline
\end{tabular}

\section{Conclusions}

To evaluate the significance of theoretical conceptions by different authors the criteria of the analysis have been determined; they are based on the methodological recommendations of The Development and Evaluation of the Content of Educational Literature in Compliance with the National General Education Standards, and partially the pedagogical evaluation criteria proposed by M. Sīle have been employed. Works by L. Kārkliņšs, J. Joffe and L. Maslenkova have been analyzed in detail. In L. Kārklinšs' work, the provided practical material seems to be of great value as it is grounded in national Latvian folklore. J. Joffe builds his system of learning intervals on the dependence of the interval group and perception on the time and metro-rhythm conditions. L. Maslenkova makes emphasis on acquiring musical heritage of the 20th c. music. Each of these scholars offers their own methodology of the development of harmonic hearing, which can partially be applied when training the prospective teachers of music.Each of these authors offers their own methodology for developing harmonic hearing, which can partially be used for training prospective teachers of music. 
L. Maslenkova's research "Intensive Course of Sol-Fa" (2003) is the most consistent and diverse among them with regard to the organization of musical material which is based on author's instructive exercises and the contemporary music. In it, the author highlights conceptual issues of teaching musical hearing. L. Maslenkova proposes her own solution to the problem of developing harmonic hearing, an original methodology for training deep, active musical hearing based on various methods of comparison, correlation and analogies.

The conceptions of the development of harmonic hearing analyzed in this research allow us to make use of the valuable experience of different authors, to apply various approaches and methods of organizing educational activities at teaching sol-fa in practice, which all are oriented towards developing harmonic hearing.

\section{Kopsavilkums}

Mūsdienās muzikālajā izglīî̄bā īpaša nozīme ir personības radošo spēju attīstībai. Jaunrade - viens no galveniem stratēgeiskiem principiem, kuru ievērošana var būtiski palielināt Latvijas ilgtspējīgas attīstības iespējas (Latvijas ilgtspējīgas attīstības stratēgija līdz 2030. gadam, 2011).

Latviešu muzikālās kultūras attīstība ir cieši saistīta ar sadziedāšanas tradīcijām. Harmoniskā dzirde - viens no muzikālās dzirdes komponentiem. Posmsecīga un mērķtiecīga harmoniskās dzirdes attīstība ir nepieciešams daudzbalsīga kora dziedājuma nosacījums. No harmoniskās dzirdes attīstības līmeņa atkarīga intonēšana kā korī, tā arī vokālajā ansamblī.

The aim of this paper is: veikt dažādu autoru koncepciju salīdzinošo analīzi harmoniskās dzirdes attīistības jautājumā.

Research methods: dažādu koncepciju salīdzinošā analīze atbilstoši noteiktiem kritēijiem.

Lai novērtētu dažādu autoru teorētisko koncepciju nozīmi, tika noteikti analīzes kritēriji. Kritēriju izstrādes pamatā ir ,,Valsts vispārējās izglìtības standartiem atbilstošas mācību literatūras satura izstrādes un izvērtēšanas" metodiskās rekomendācijas, ko izstrādāja Latvijas Universitātes Pedagoǵijas un psihologijas katedras zinātnieki (Valsts vispārējās izglîtības standartiem atbilstošas mācību literatūras satura izstrāde un izvērtēšana, 2010). Daḷēji tika izmantoti arī M. Sīles pedagoǵiskā vērtējuma kritēriji (Sīle, 2003).

Koncepciju analīzei tika izvēlēti šādi kritēriji:

Sistēmiskums;

Sistemātiskums;

Didaktiska materiāla izkārtojuma princips;

Praktiska mūzikas materiāla atlases princips.

Latviešu mūzikas pedagog̣ijas literatūrā tikai divi autori piedāvā savas harmoniskās dzirdes attīstības koncepcijas: L. Kārkliņš Mūzikas teorētisko priekšmetu mācǐšanas metodika (1963) un J. Joffe Muzikālās dzirdes attīstības ceļi (1991). 
Interesi saista zviedru autora L. Edlund mācību palīglīdzeklis Modus novus (1963) mūsdienu mūzikas intonēšanai un dzirdes uztverei (analīzei).

Intervālu pieeja kā harmoniskās dzirdes attīstības pamats skaņu kompleksa elementu uztveres rezultātā raksturo franču skolu - Y. Desportes Comment former l'oreille musicale (1970).

Dažas rekomendācijas akordu noteikšanai (analīzei) pēc dzirdes piedāvā latviešu vadošā mūsdienu muzikoloǵe I. Grauzdiṇa savā darbā Dzirdes analīze bērnu mūzikas skolu solfedžo nodarbībām (1975).

L̦. Maș̦enkovas grāmata Интенсивный курс сольфеджио (2003) - viens no mūsdienu metodiskajiem darbiem, kurā skatīti muzikālās dzirdes attīstības jautājumi un kas domāts solfedžo pasniedzējiem.

Viens no pēdējiem konceptuālajiem darbiem, kas veltīts muzikālās dzirdes jautājumiem, ir M. Karasjevas Сольфеджио - психотехника развития музыкального слуха (2009). Grāmatā izstrādāta mūsdienu solfedžo mācību metodika, balstīta geštaltpsihologijā un neirolingvistiskajā programmēšanā.

Pētîjumā veikta detalizētāka L.Kārkliņa, J.Joffes un L.Maslenkovas darbu analīze atbilstoši piedāvātajiem kritērijiem un izstrādāta salīdzinošā tabula. Katrs autors piedāvā savu harmoniskās dzirdes analīzes metodiku, kas dạ̦ēji pielietojama arī topošo mūzikas skolotāju sagatavošanas praksē.
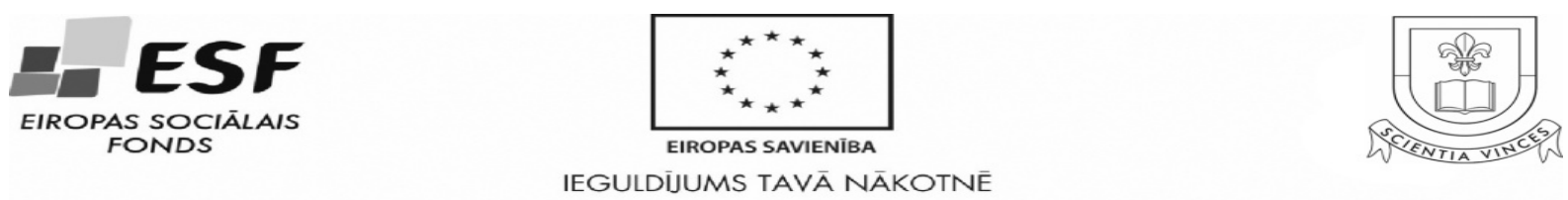

This work has been supported by the European Social Fund within the Project "Support for the implementation of doctoral studies at Daugavpils University" Agreement Nr. 2009/0140/1DP/1.1.2.1.2/09/IPIA/VIAA/015

\section{Literatūra \\ Bibliography}

1. Birzkops, J. (2000). Attīstošā klavierspēle. [Piano playing for the Development] Rīga.: Musica Baltica.

2. Desportes, Y. (1970). Comment former l'oreille musicale. Paris: Editions Max Eschig

3. Edlund, L. (1963). Modus novus. Larobok i fritonal melodilasning (Lehrbuch in freitonaler Melodielesung / Studies in Reading Atonal Melodies). Stockholm: Edition Wilhelm Hansen.

4. Grauzdiņa, I. (1975). Dzirdes analīze bērnu mūzikas skolu solfedžo nodarbībām. [Analysis of Musical Hearing for Sol-Fa Classes in Children's Music Schools] Rīga: Mācību iestāžu metodiskais kabinets.

5. Joffe, J. (1991). Ways of the Development of Musical Hearing. Riga: Zvaigzne.

6. Karaseva, М. (2009). Сольфеджио - психотехника развития музыкального слуха [Sol-Fa - Psychotechnique of the Development of Musical Hearing]. Moskow: Kompozitor (In Russian).

7. Kārkliņš, L.(1963). Mūzikas teorētisko priekšmetu mācīšanas metodika. [Methodology of Teaching Theoretical Subjects in Music] Rīga: Latvijas Valsts izdevniecība.

8. Latvijas ilgspējìgas attīstības stratēgija lìdz 2030. gadam.

9. from http://www.latvija2030.lv/umpload/latvija2030_saeima.pdf (01.01.2011). 
10. Mezīte, M., \& Znutiņš, E.(2009). Skaņdarba apgūšanas metodiskie paņēmieni darbā ar pašdarbības koriem [Materials of the international scientific conference Methodological techniques for mastering a composition with amateur choirs] DU 50. Starptautiskās zinātnuskās konferences materiāli 50-55,p. Daugavpils: Saule.

11. Maslenkova, L. (2003). Интенсивный курс сольфеджио [Intensive Course in Sol-Fa. Methological Aid for Teacher]. St. Peterburg: Sojuz Hudozhnikov.

12. Sīle, M. (2003). Latvijas klavierspēles skolas attīstība. [The Development of Latvian Piano School] Rīga: RaKa.

13. Valsts vispārējās izglītības standartiem atbilstošas mācību literatūras satura izstrāde un izvērtēšana. from http://www.visc.gov.lv/saturs/vispizgl/metmat.shtmt (28.10.2010)

\begin{tabular}{|r|l|}
\hline Gal̦ina & Daugavpils Universitāte \\
Zavadska & Saules1/3, MMF, Daugavpils, \\
& E-pasts: g.zavadska@,inbox.lv \\
& Tel. : +371 26568474 \\
\hline
\end{tabular}

